\title{
Performance of Mulching to the Stimulation on the Growth of Cucumber (Cucumis Sativus) Production
}

\author{
Daliya Akter \\ Department of Agriculture \\ Noakhali Science and Technology University, Noakhali- 38I4, Bangladesh \\ E-mail: daliyaakter26@gmail.com \\ Mohammad Shafiqul Islam \\ Assistant Professor \\ Department of Agriculture \\ Noakhali Science and Technology University, Noakhali-38I4, Bangladesh \\ E-mail: safi.agri21@gmail.com \\ Roksana Aftab Ruhi \\ MS Student \\ Department of Plant Pathology \\ Faculty of Agriculture \\ Sher-e-Bangla Agricultural University, Dhaka-I207, Bangladesh \\ E-mail.: ruhi435@outlook.com \\ Md Istiak Hossain Joy \\ Department of Agriculture \\ Noakhali Science and Technology University, Noakhali-38I4, Bangladesh \\ E-mail: istiakjoy40@gmail.com \\ Fariha Ahmed Trina \\ Department of Agriculture \\ Noakhali Science and Technology University, Noakhali-38I4, Bangladesh \\ E-mail: farihaahmedtrina@gmail.com
}

Received: August 2I, 2020

doi: 10.4628I/bjmsr.v2i2.777
Accepted: September I3, 2020

Online Published: September 2I, 2020

URL: https://doi.org/I0.4628I/bjmsr.v2i2.777

\begin{abstract}
A field experiment was conducted at Noakhali,Chittagong during the season in 2019, to determine the effect of mulching on cucumber (Cucumis sativus) production where Alavy Green variety was used. The study was laid out in RCBD (Randomized complete block design) method having three replications. The treatment used in this study consists of $T_{\mathrm{I}}=\mathrm{Black}$ plastic mulching, $T_{2}=$ Water hyacinth mulching, $T_{3}=$ Rice straw mulching, Control= no mulching. The plant showed significant differences after application of various treatments. The maximum average length of vine (II3 cm), number of branch per plant (8.33), number of leaves per plant (28.44), number of tendrils per plant (I I.52), number of flowers per plant (I6.33), number of fruits per plant (9), length of fruit (I8 cm), weight of individual fruit $(239.67 \mathrm{~g})$ were obtained from $\mathrm{T}_{\mathrm{I}}$ treatment (Black plastic mulching). On the other hand, minimum average length of vine (I03.9I cm), number of branch per plant (4.33), number of leaves per plant (22.67), number of tendrils per plant (7.33), number of flowers per plant (I2.33),number of fruits per plant (4.33), length of fruit $(9 \mathrm{~cm})$, weight of individual fruit $(173.67 \mathrm{~g}$ ) were obtained from To control (No mulching). Among organic (Water hyacinth and Rice straw) and inorganic mulches (Black plastic), inorganic mulches gave better performance over organic mulches.
\end{abstract}

Keywords: Cucumber, Mulching, Growth, Development, Yield. 


\section{Introduction}

In Bangladesh, to meet the vegetable deficiency during the scarce period Cucumber plays a great role which ultimately diminishes the malnutrition problem. Total cultivable land of cucumber is about 22286 acres and total production is approximately 54854 metric tons (Bangladesh Bureau of Statistics, 20I4) gained in Bangladesh. It was found effective against human constipation and improvement in digestion. It is eaten as a cooling food in summer and a fresh Cucumber provides vitamin C, niacin, iron, calcium, thiamine, fibre sand phosphorus (Maurya, Pal, Singh, \& Meena, 2015). In general, Cucumber (Cucumis sativus L.) is one of the most popular vegetable of the Cucurbitaceae family (Lower \& Edwards, 1986; Thoa, I998). After tomato, cabbage and onion in Asia (Tatlioglu, 1997) this crop is the fourth vegetable crop. It is a annual crop which leaves are alternate, simple and triangular-ovate with 3-7 lobed leaf blades, deeply chordate at the base. Besides the vines that are sparingly branched are produced from stem that are certainly creeping type which roots in the ground grows up trellises or other supporting frames, wrapping around supports with thin, spiralling tendrils (Mariod, Mirghani, \& Hussein, 20I7). The Cucumber plant can also root in a soilless medium and sprawl along the ground if it does not have supports around it. The farmers of Cumilla, Bogra, Rangpur, Noakhali, Faridpur, Chittagong and Mymensingh districts in Bangladesh are grow cucumber commercially. It is enlisted as a profitable business due to it's relatively higher net return per hectare cost. Since the soil and climatic condition of Bangladesh are compatible to cultivate cucumber exponentially, it is expected the selection of high yielding varieties will augment the yield considerably. Indeed there is a vast scope to increment production with the introduction of high yielding varieties. Mulching is a technique that has been applied by vegetable growers for many years and prescribed to use either organic or inorganic materials. To help farmers to obtain their production goals such as earliness, soil moisture retention, improved quality, weed control and increased yields several kinds of soil and plant mulching materials are available (Mutetwa \& Mtaita, 20I4) .Besides, mulches, as a natural or synthetic substances cover the soil surface to protect and flourish it's quality in landscapes (Cregg \& Schutzki, 2009). However, the bare soil revealed to heat and the wind loses water through evaporation while using mulches increases the soils water retention capacity, reduces evaporation and number of weeds as well (Plekhanova $\&$ Petrova, 2000) even it moderates soil moisture and temperature (Skroch, Powell, Bilderback, \& Henry, 1992) also. Usage of different kinds of mulches such as black polythene, rice straw, water hyacinth, saw dust, leaves, hay, shredded bark, shells, woodchips, newspaper, cardboard etc. has been reported to have developed fruit quality (Brown \& Channell-Butcher, 200I), increased growth and subsequent yield. Among all of the mulching materials black polythene and rice straw water hyacinth are profitable and available in our country, Bangladesh. Black plastic mulch is the most popular one because it suppresses weed growth and warms up the soil during the spring. Moreover the black plastic mulch helps in the harvesting earlier in addition to reduce soil water losses. Thus the study was conducted to found out the effects of these several mulching on cucumber production mainly on its growth, development and yield performances.

\section{Methodology \\ 2. I Experimental Site}

On the basis of the potentiality, the experiment had been done at Navogram Farm in Mannan Nagar union which is situated at sadar upazila in, Noakhali 2019 that is fall under the Agroecological Zone (AEZ) I8 i.e. Young Meghna Estuarine Floodplain, annually inundated and fertilized by silt deposit from the Meghna estuary (Figure I). As it was located in the tropical climatic zone where the average annual temperature is $25.6^{\circ} \mathrm{C}$ and about $2980 \mathrm{~mm}$ precipitation falls annually. The average maximum temperature during September to December is $28.1^{\circ} \mathrm{C}$ which was suitable for cucumber production at that region in Bangladesh. (Table I). The soil of the experimental plots was sandy loam in texture, medium high land and it was moderately alkaline with $\mathrm{pH}$ value $7.3-8.3$ with salinity $>2 \mathrm{dS} / \mathrm{m}$, Organic matter $0.64 \%$, Nitrogen $0.04 \%$, Phosphorus 27.27\%,Potassium $0.18 \%$ individually. Physical and Chemical characteristics of soil in research plots were noted from Soil Resource and Development Institute (SRDI) 




Figure I. Map Showing the Research Site

Table I. Monthly Average Climatic Condition of the Experimental Site during the Research

\begin{tabular}{cccccc}
\hline Month & \multicolumn{3}{c}{ Temperature (0C) } & Relative humidity \% & $\begin{array}{c}\text { Total } \\
\text { Rain fall (mm) }\end{array}$ \\
\cline { 2 - 5 } & Maximum & Minimum & Average & & 60.5 \\
\hline September & 32 & 26 & 29 & 89.25 & 100.25 \\
\hline October & 34 & 25 & 28 & 80.75 & 3.25 \\
\hline November & 32 & I7.9 & 28 & 56.5 & 00 \\
\hline December & 26.I & I5.5 & 20.8 & & \\
\hline
\end{tabular}

Source: Weather Station of Noakhali District, Bangladesh

\subsection{Experimental Materials}

The material used in the research was Alavy Green variety of cucumber which was collected from Bangladesh Agricultural Research Institute (BARI). For mulching certainly three types such as black plastic, water hyacinth, rice straw were used. Organic and inorganic fertilizer, pesticide and other materials were collected from Dotterhat Seed Ghor in Noakhali.

\subsection{Experimental Design and Treatment}

The experiment was arranged in Randomized Complete Block Design (RCBD) with three replications. In this experiment, four treatments were considered as following-

To(Control): No mulching

Tr: Black plastic mulching.

$\mathrm{T}_{2}$ : Water hyacinth mulching.

$T_{3}$ : Rice straw mulching.

\subsection{Land Preparation}

The selected land for the experiment was ploughed at first day of September in 2019 than it was kept open to sun for 4 days prior to further ploughing. Eventually, the land was prepared well by ploughing and cross ploughing followed by well laddering .The unit plots were prepared by keeping $1 \mathrm{~m}$ spacing in between two plots and $50 \mathrm{~cm}$ draining channel was dug around the 
land. There were three pits in every plot. The length and breadth of each pit was $30 \mathrm{~cm}$ and $30 \mathrm{~cm}$ respectively. Pits were $20 \mathrm{~cm}$ depth and $45 \mathrm{~cm}$ distance from the border of the plots.

\subsection{Seed Sowing and Fertilizers Application}

The seeds were sown directly in the pit where three seeds were sown in each pit at 2 to $3 \mathrm{~cm}$ depth. Different mulching materials were applied after IO days of seed emergence. Manures and fertilizers applied uniformly in the experimental plots and pits as per following doses (Table 2) in accordance with the recommended dose.

Table 2. Fertilizers Doses Applied on the Research Field

\begin{tabular}{ccc}
\hline Fertilizers & \multicolumn{2}{c}{ Recommended Dose } \\
\cline { 2 - 3 } & Dose per Plot & Dose per Pit \\
\hline Cowdung & $6 \mathrm{~kg}$ & $\mathrm{I} \mathrm{kg}$ \\
\hline Urea & $90 \mathrm{~g}$ & $\mathrm{I} 5 \mathrm{~g}$ \\
\hline Triple Super Phosphate & $75 \mathrm{~g}$ & $\mathrm{I} 2.5 \mathrm{~g}$ \\
\hline Murate of Potash & $60 \mathrm{~g}$ & $\mathrm{I}$ \\
\hline
\end{tabular}

\subsection{Intercultural Operations}

Weeding was done whenever necessary to keep the crop free from weeds. When the seedlings were established, staking was given to each plant. For proper growth and development of the plants the vines were managed upward by hand and with the help of iron rope and nylon net. Light over-head watered were provided with a watering can to the plots immediately after germination of seedlings. The un-mulched plot had to be watered more frequently than the mulch plots.

\subsection{Data Collection}

Length of main vine, no. of lateral branches/ plant, no. leaves/ plant, no. tendrils/plant, no. of flowers/plant, no. of fruits/plant, individual fruit weight, fruit length parameters data were recorded from the experimental plot (from the plant with: Black plastic mulching, Water hyacinth mulching, Rice straw mulching, No mulching and pruning)

\subsection{Experimental Design}

The experiment was laid in the Randomized Complete Block Design (RCBD) with one variety and 4 treatments and the experiment was replicated 3 times.

\subsection{Statistical Analysis}

The recorded data on the different parameters of the study were analyzed statistically using Analysis of Variance (ANOVA) procedure by $\mathrm{F}$ test (Gomez \& Gomez, 1984) $\mathrm{P}<0.05$ was considered statistically significant.

\section{Result and Discussion}

\section{I Length of Main Vine (cm)}

Length of main vine varied significantly due to the application of treatments on cucumber plant. Average lengths of main vine were $I I 3 \mathrm{~cm}, 107.97 \mathrm{~cm}, 105.98 \mathrm{~cm}$ and $103.9 \mathrm{Im}$ respectively for $T_{1}, T_{2}, T_{3}$ and $T_{0}$. The highest value recorded at $T_{1}$ treatment which was $113 \mathrm{~cm}$ whereas the lowest value observed in $T_{0}$ treatment (Figure 2). Similar results were found where Ajibola and Amujoyegbe (2019) recorded highest length of cucumber (II3.2I cm) after application of black plastic mulch in their works. 


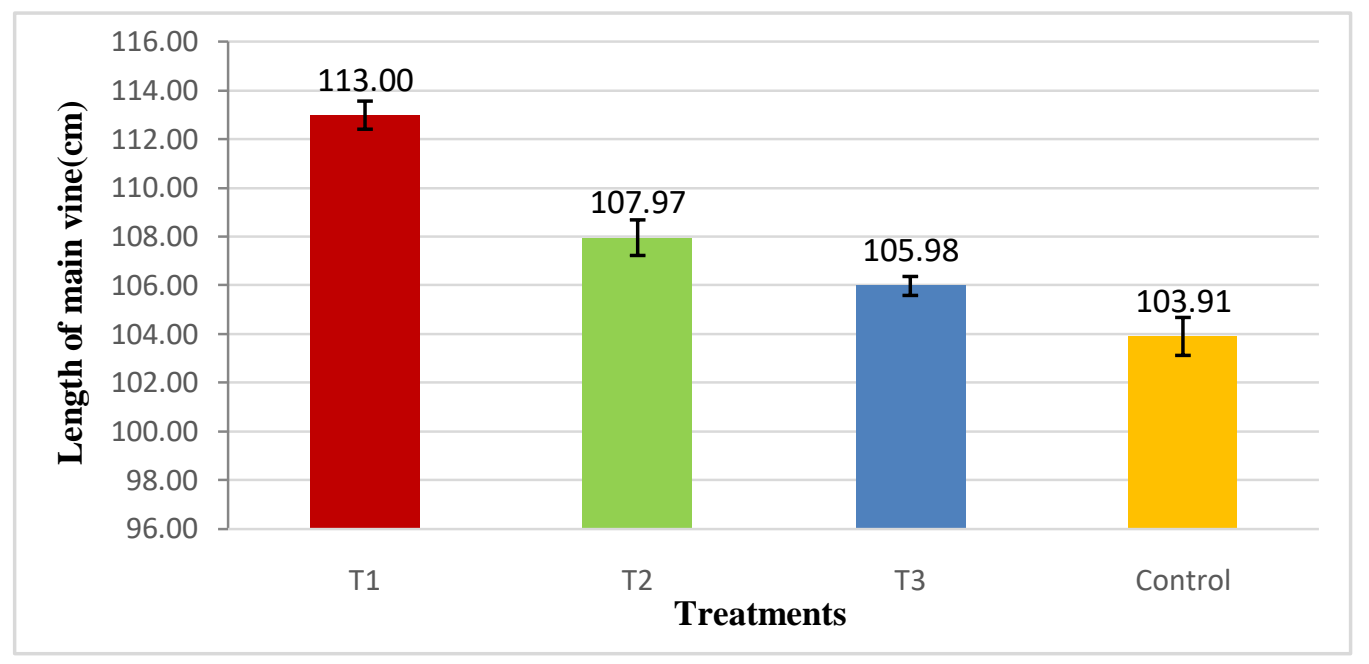

Figure 2. Effects of Different Treatments on the Length of Main Vine (cm)

\subsection{No. of Branches per Plant}

Application of different treatments (black plastic mulching, water hyacinth mulching, rice straw mulching and no mulching show significant $(\mathrm{P}<0.05)$ variation on the number of branches produced in each plant. From Figure.3, the average no. of branches was 8.33, 6.83, 5.50 and 4.33 respectively for the treatment of $T_{1}, T_{2}, T_{3}$ and $T_{4}$. The topmost value was observed for $T_{1}$ i.e. 8.33 and minimum value obtained for $\mathrm{T}_{0}$ that was 4.33.This agreement is similar to the experiment of Ajibola and Amujoyegbe (2019) where they got highest number of lateral branches (5.68) after application of black plastic mulch.

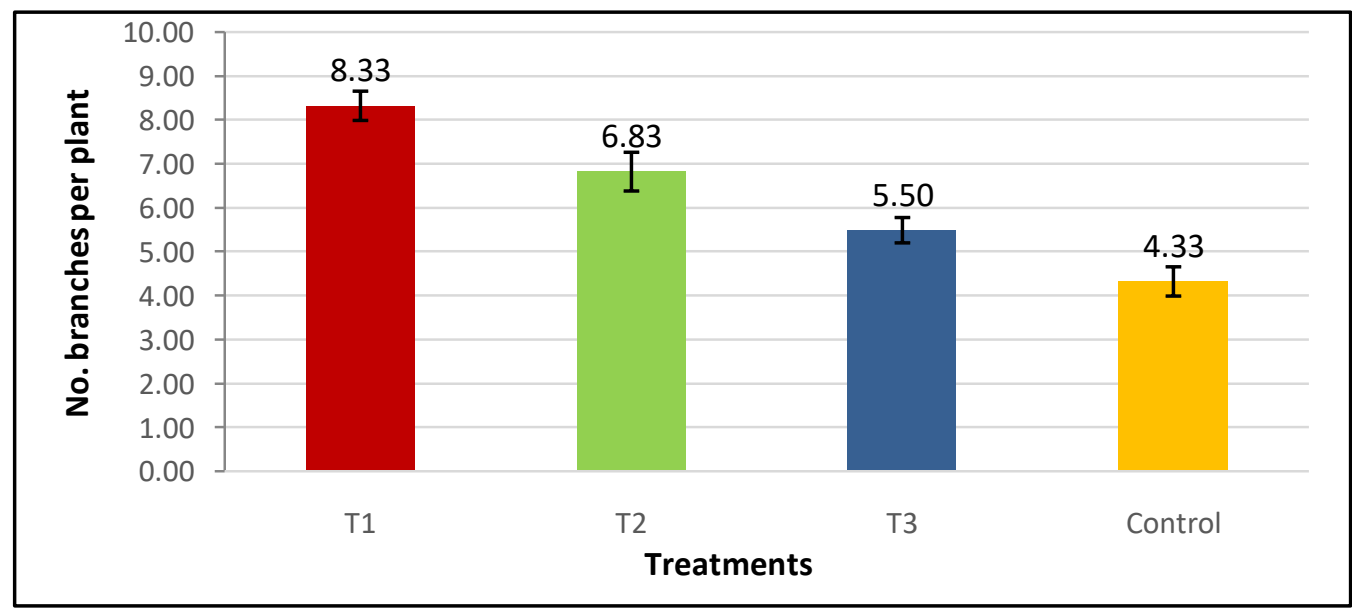

Figure 3. Effects of Different Treatments on the Number of Branches per plant

\subsection{No. of Leaves per Plant}

Figure.4 was illustrated that the maximum value obtained for $\mathrm{T}_{\mathrm{I}}$ (black plastic mulching) was 28.33 while the minimum value found from $T_{0}$ (no mulching method) treatments which was 22.67. Ajibola and Amujoyegbe (2019) support the current result as they also found highest number of leaves in each plant after application of black plastic mulch. 


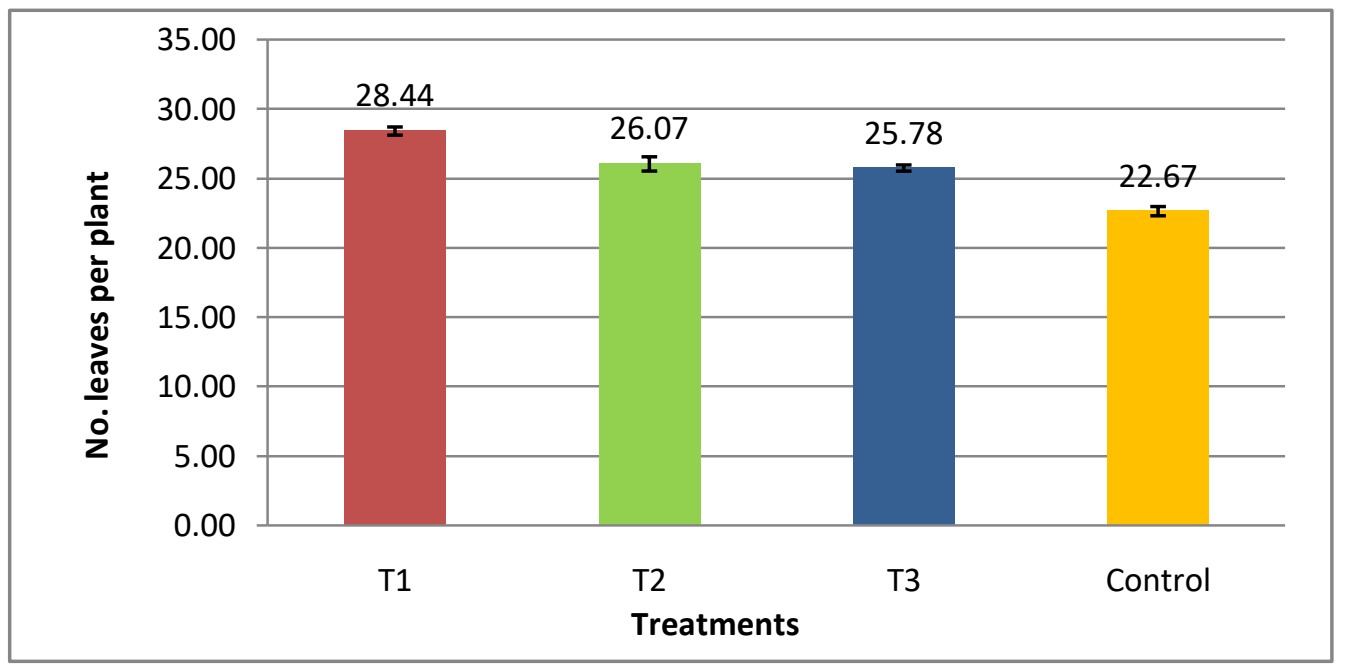

Figure 4. Effects of Different Treatments on Leaves Number per Plant

\subsection{Number of Tendrils per Plant}

In case of tendrils number different mulching materials exhibited significant $(\mathrm{p}<0.05)$ variation. Figure 5 showed that the highest number of tendril observed for $T_{\text {I }}$ i.e. I I.52 whereas lowest obtained for $T_{0}$ treatment that was 7.33. Similar result revealed in Ajibola and Amujoyegbe (2019) studies.

\subsection{Number of Flowers per Plant}

A significant $(\mathrm{p}<0.05)$ different was observed on the production of flower per plant where the average number of flowers per plant were 16.33, I5.67, I4.00 and I2.33 individually for all treatments (Figure 6). However, the treatment of $\mathrm{T}_{\mathrm{I}}$ produced maximum number (I6.33) in comparison with other treatments and the minimum (I2.33) was recorded in $T_{0}$ treatment (no mulching). It was confirmed by Wien, Minotti, and Grubinger (1993) who reported that mulching increased number of flower cluster on main branches and secondary branches compared with no mulch.



Figure 5. Effects of Different Treatments on Tendril Numbers per Plant 


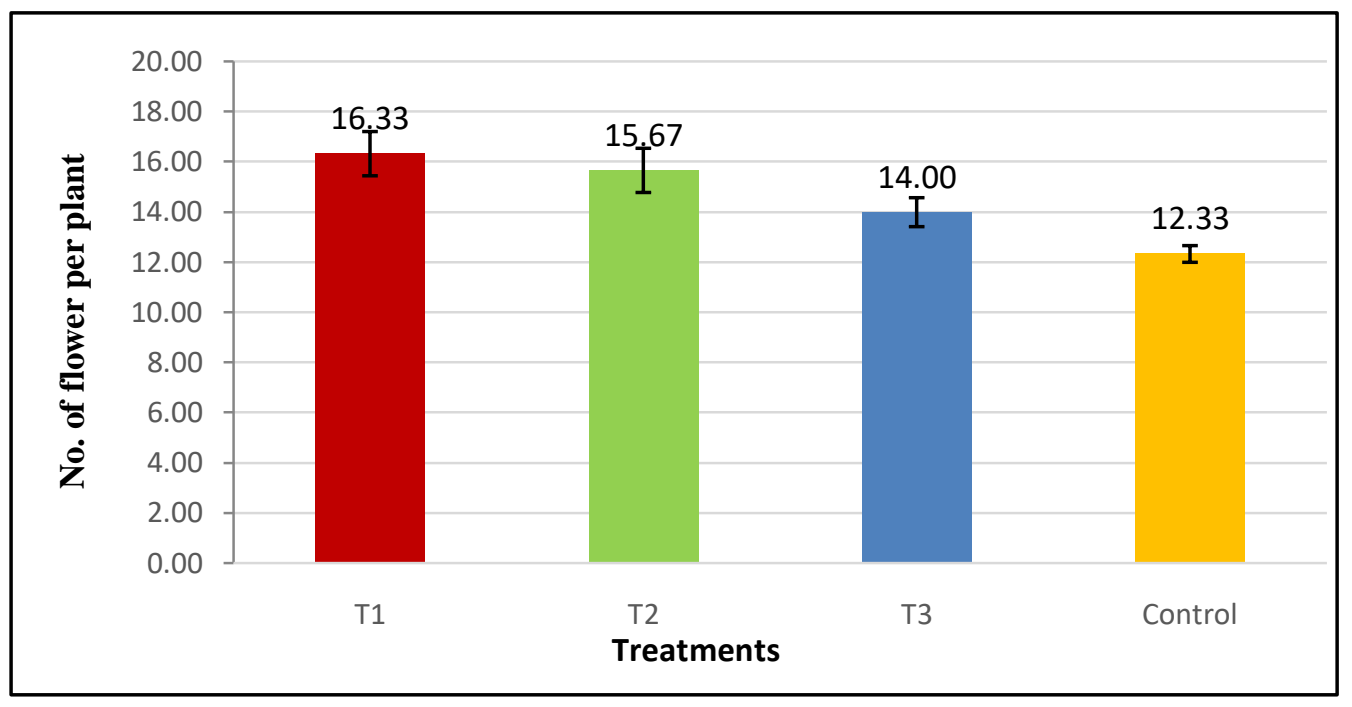

Figure 6. Effects of Different Treatments on Flower Number Per Plant

\subsection{No. of Fruits per Plant}

Significant variation $(\mathrm{P}<0.05)$ was seen due to the application of mulching materials in case of fruits number. The maximum fruits obtained for $T_{1}$ treatment which was 8.78 and minimum number found from $T_{0}$ treatment (no mulching method) that was 4.17 (Figure.7) Nair, Carpenter, and Weieneth (2013) were agreed with the provided result as they also got similar outcome by using black plastic mulch which gave maximum fruits in their research works.

\subsection{Weight of Individual Fruit (g)}

The average weight of individual fruit were $239.67 \mathrm{~g}, 212.00 \mathrm{~g}, \mathrm{I} 92.67 \mathrm{~g}$ and $173.67 \mathrm{~g}$ respectively for black plastic mulching $\left(T_{1}\right)$, water hyacinth mulching $\left(T_{2}\right)$, rice straw mulching $\left(T_{3}\right)$ and no mulching $\left(T_{0}\right)$ treatments used in the experiment. The highest weight obtained $239.67 \mathrm{~g}$ for $\mathrm{T}_{\mathrm{I}}$ and on the other hand the lowest weight was found from $\mathrm{T}_{0}$ treatment which was I73.67g (Figure 8) which is clarified by Nair et al. (2013) where they claimed that using of black plastic mulch gave highest weight of fruit.



Figure 7. Effects of Different Treatments on the Number of Fruits per Plant 


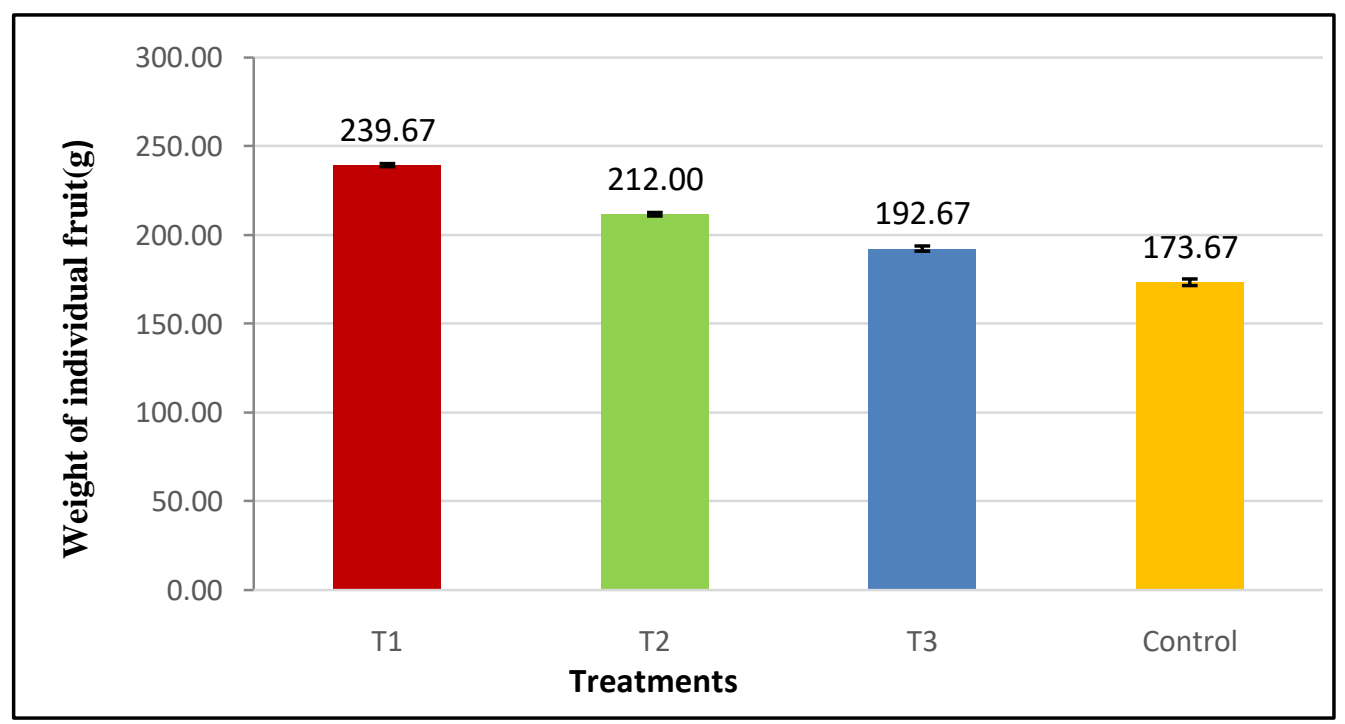

Figure 8. Effects of Different Treatments on Weight of Individual Fruit (g)

\subsection{Length of Fruit $(\mathrm{cm})$}

Length of each fruit varied significantly due to the application of different mulching materials on cucumber plant where the highest length obtained $I 8 \mathrm{~cm}$ for Titreatment and lowest length recorded $9 \mathrm{~cm}$ for $T_{0}$ (Figure 9). Both Ajibola and Amujoyegbe (2019) and Nair et al. (2013) conducted research were agreed with the results of the current experiment as they also found black plastic mulch was better than other materials to get highest length of fruits in cucumber.

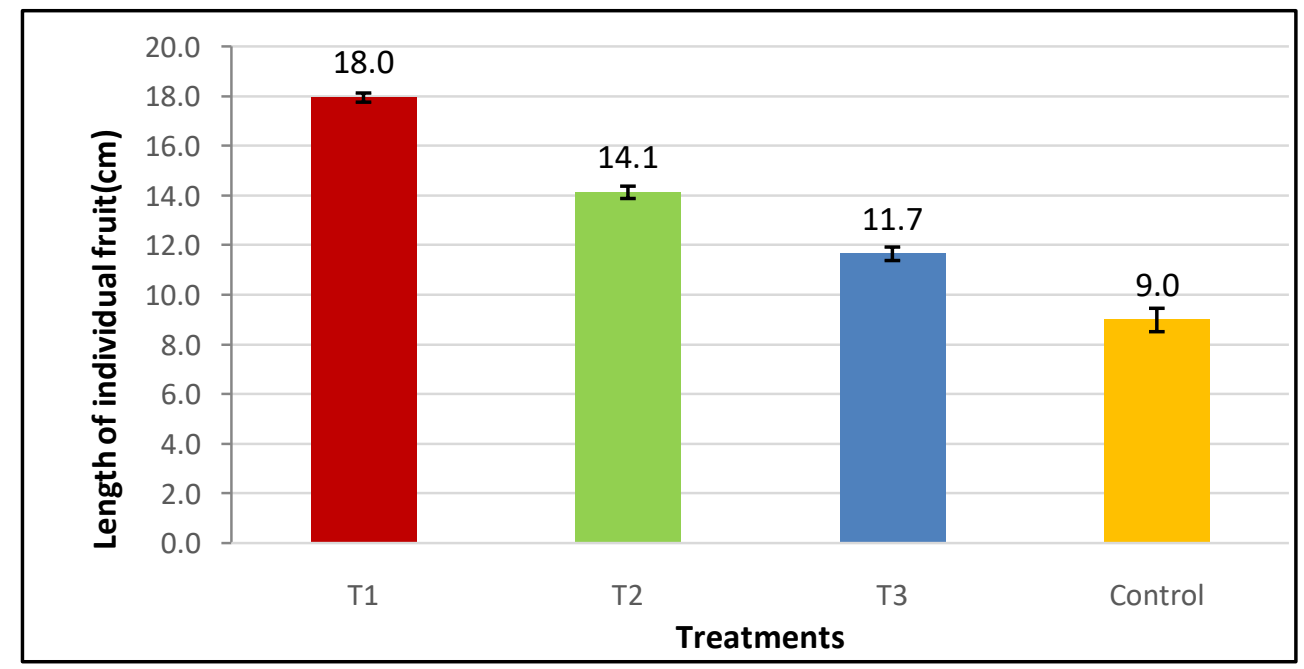

Figure 9. Effects of Different Treatments on the Length of Individual Fruit $(\mathrm{cm})$

\section{Conclusion}

Some cultural practices such as mulching can be used for cucumber production. It is the practice of covering the soil to make more favourable condition for plant growth, development and efficient crop production. Water hyacinth, straw, saw dust, rice husk and black polythene are available to the farmers and resulted in reduced soil water loss by evaporation and controlling weeds. All treatments used in the experiment showed significant variation on the growth and yield contributing parameters. After the study, it can be said that if farmers used proper mulching, it will give maximum growth and yield per stated area. From the study it can be recommended that application of different mulches in cucumber production will provide economically viable results as compared to no mulch condition. 


\section{References}

Ajibola, O. V., \& Amujoyegbe, B. J. (2019). Effect of Seasons, Mulching Materials, and Fruit Quality on a Cucumber (Cucumis sativus L.) Variety. Asian Journal of Agricultural and Horticultural Research, III.https://doi.org/I0.9734/ajahr/20I9/v3i229996

BBS (Bangladesh Bureau of Statistics). (20I4). Yearbook of Agricultural Statistics: Ministry of Planning, Government of the People's Republic of Bangladesh, Dhaka, Bangladesh.

Brown, J. E., \& Channell-Butcher, C. (I999). Effects of row cover and black plastic mulch on yield of 'AU Producer' watermelon on hilled and flat rows. Journal of vegetable crop production, 5(I), 677I.https://doi.org/I0.1300/J068v05n0I_07

Cregg, B. M., \& Schutzki, R. (2009). Weed control and organic mulches affect physiology and growth of landscape shrubs. HortScience, 44(5), I4I9-I424.https://doi.org/I0.21273/HORTSCI.44.5.14I9

Gomez, K. A., \& Gomez, A. A. (1984). Statistical procedures for agricultural research. John Wiley \& Sons.

Lower, R. L. (1986). Cucumber breeding. Breeding vegetable crops.Westport, Connecticut USA: AVI Publishing Co.I73-203.

Mariod, A. A., Mirghani, M. E. S., \& Hussein, I. H. (2017). Unconventional oilseeds and oil sources. Academic Press. eBook ISBN: 9780I28134337/Paperback ISBN: 9780I28094358

Maurya, G. P., Pal, V. I. V. E. K., Singh, G. P., \& Meena, L. K. (2015). An economic analysis of cucumber cultivation in Sultanpur District of Uttar Pradesh (India). Int J AgricSci Res, 5, 23-27.

Mutetwa, M., \& Mtaita, T. (2014). Effects of mulching and fertilizer sources on growth and yield of onion .

Nair, A., Carpenter, B. H., \& Weieneth, L. K. (2013). Effect of plastic mulch and trellises on cucumber production in high tunnels. Iowa State University Research and Demonstration Farms Progress Reports, 20I2(I).http://lib.dr.iastate.edu/farms_reports/I909

Plekhanova, M. N., \& Petrova, M. N. (2000). Influence of black plastic soil mulching on productivity of strawberry cultivars in Northwest Russia. In IV International Strawberry Symposium 567 (pp. 49I494).https://doi.org/I0.I7660/ActaHortic.2002.567.104

Skroch, W. A., Powell, M. A., Bilderback, T. E., \& Henry, P. H. (I992). Mulches: durability, aesthetic value, weed control, and temperature. Journal of Environmental Horticulture, IO(I), 43-45.https://doi.org/I0.24266/0738-2898-I0.I.43

Tatlioglu, T. (1997). Cucumber (Cucumissativus L.) In: Kailov, G and Bo Bergn, (eds.). Genetic improvement of vegetable crops. Oxford Pergamon Press. pp. 197-227.

Thoa, D.K. (1998). Cucumber seed multiplication and characterization. AVRDC/ARC Training Thailand, pp.5-I0.

Wien, H. C., Minotti, P. L., \& Grubinger, V. P. (1993). Polyethylene mulch stimulates early root growth and nutrient uptake of transplanted tomatoes. Joumal of the American Society for Horticultural Science, II8(2), 2072II.https://doi.org/I0.2I273/JASHS.I I8.2.207

\section{Copyrights}

Copyright for this article is retained by the author(s), with first publication rights granted to the journal. This is an open-access article distributed under the terms and conditions of the Creative Commons Attribution license (http://creativecommons.org/licenses/by/4.0/). 